\title{
Immunoglobulin Lambda-Like Polypeptide 1
}

National Cancer Institute

\section{Source}

National Cancer Institute. Immunoglobulin Lambda-Like Polypeptide 1. NCI Thesaurus. Code C118232.

Immunog lobulin lambda-like polypeptide 1 (213 aa, $\sim 23 \mathrm{kDa}$ ) is encoded by the human IGLL1 gene. This protein plays a role in both B-cell development and pre-B-cell receptor complex formation. 